\title{
FENOMENA PENGGUNAAN BAHASA NONVERBAL DALAM DAKWAH KULTURAL
}

\section{Rahma Dini Warastuti}

Dosen Tetap Fakultas Tarbiyah dan Ilmu Keguruan IAIN Palu

\section{Abstract;}

The current social situation shows social problems and deviant behavior. In such condition, Allah gives rules, which contain His commands and prohibitions, and asks people to do according to Allah's rules, and to avoid from what He forbids. From this condition, Islamic preach (da'wah) is needed, which promotes Islamic shari'ah covering all aspects of life. Therefore, Islamic da'wah demands a myriad of approaches, methods, media, message, actors and partners of da'wah. From this, cultural da'wah model emerged, by which those who were not categorised as a preacher are excited to preach through non-verbal language, such as giving a good example, wisdom, community empowerment, and so forth. This kind of da'wah is proved to be quite effective and successful.

$$
\begin{aligned}
& \text { ويشير الموقف الاجتاعي الحالي إلى المثكلات الاجتماعية و السلوك المنحرف. وفى هذه الحالة، يعطي الله }
\end{aligned}
$$

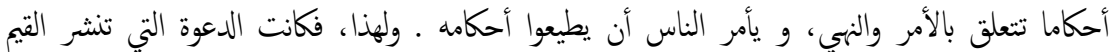

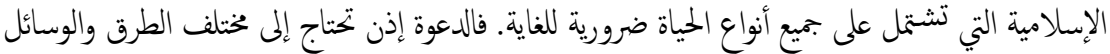

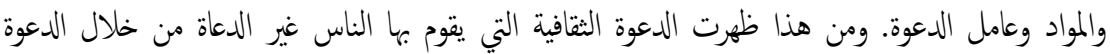

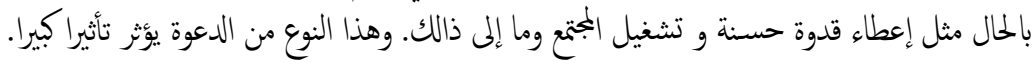

Kata Kunci: dakwah, kultural, bahasa, nonverbal

\section{Pendahuluan}

Kemajuan sains dan teknologi, industrialisme dan urbanisasi telah memunculkan banyak masalah sosial pada masyarakat modern. Gejala-gejala seperti keseimbangan, kebingungan, kecemasan, dan konflik-konflik menjadi pemandangan sehari-hari. Dampak dari kondisi tersebut memicu orang untuk melakukan tingkah laku menyimpang dari norma-norma masyarakat bahkan norma-norma Islam. Situasi sosial ini menimbulkan masalah sosial atau tingkah laku menyimpang seperti korupsi, kolusi dan nepotisme (KKN), maraknya kriminalitas (pencurian, 
Rahma Dini Warastuti, Fenomena Penggunaan Bahasa....

penodongan dan pembunuhan), deviasi seksual, dan seterusnya. Peningkatan kriminalitas menunjukkan kondisi yang sangat memprihatinkan, bahkan bentuknya sudah berada di luar batas kemanusiaan dan akal sehat.

Dalam kondisi yang demikian, Islam sebagai sistem kehidupan yang komprehensif mampu menyelesaikan masalah kriminalitas ini dengan langkah-langkah preventif yang cukup efektif. Langkah preventif tersebut adalah meningkatkan pemahaman ajaran agama yang telah melarang setiap individu untuk melakukan tindakan maksiat. Dalam ajaran agama Islam, jangankan melakukan kejahatan, mendekati pun sudah diharamkan. Ajaran ini, jika tertanam dengan kuat dalam diri setiap individu, maka seorang Muslim tidak akan melakukan tindak kejahatan dalam bentuk apa pun. Islam menganggap bahwa kejahatan adalah perbuatan-perbuatan tercela (alqābih). Ketika shara' telah menetapkan bahwa perbuatan itu tercela, maka sudah pasti perbuatan tersebut disebut kejahatan, tanpa melihat lagi apakah tingkat dan jenis kejahatan tersebut besar ataupun kecil. Shara' telah menetapkan perbuatan tercela sebagai dosa (dhunub) yang harus dikenai sanksi. Jadi, dosa itu substansinya adalah kejahatan. Kejahatan sendiri bukan berasal dari fitrah manusia. Kejahatan bukan pula semacam "profesi" yang diusahakan oleh manusia. Kejahatan bukan juga 'penyakit' yang menimpa manusia. Kejahatan adalah tindakan melanggar aturan yang mengatur perbuatan-perbuatan manusia dalam hubungannya dengan Rab-nya, dengan dirinya sendiri, dan hubungannya dengan manusia lain. Oleh karena itu, ketika Allah mengatur perbuatan-perbuatan manusia, Allah juga telah mengatur pemenuhan terhadap naluri-naluri dan kebutuhan jasmani yang diatur dan sesuai hukum Islam. Shariat Islam telah menjelaskan kepada manusia tentang hukum atas setiap peristiwa yang terjadi. Itu sebabnya Allah men-shari'at-kan halal dan haram. Shara' mengandung perintah dan larangan-Nya, dan Allah SWT. meminta manusia untuk berbuat sesuai dengan apa yang diperintahkan Allah SWT. dan menjauhi apa yang dilarang-Nya. Jika menyalahi hal tersebut, maka manusia telah melakukan perbuatan tercela, yakni melakukan kejahatan. Oleh karena 


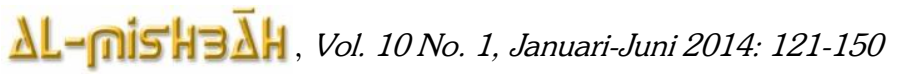

itu, orang-orang yang berdosa akan memperoleh sanksi ('iqab). Dengan demikian, manusia dituntut untuk mengerjakan apa yang diperintahkan Allah dan menjauhi larangan-Nya. Dari kondisi itulah dibutuhkan dakwah Islam yang akan menjunjung syariat Islam yang meliputi wilayah yang luas mencakup semua aspek kehidupan. Oleh karena itu, dakwah Islam ini menuntut adanya keragaman bentuk, metode, media, pesan, pelaku dan mitra dakwah, artinya setiap diri orang muslim dengan berbagai macam latar belakang harus menyadari bahwa kondisi sosial yang sudah tidak sehat ini menuntut mereka untuk aktif terlibat dalam kegiatan dakwah, baik sebagai mitra dakwah atau justru sebagai pedakwah. Dakwah adalah denyut nadi Islam, ${ }^{1}$ artinya jika kehidupan islami menjadi suatu sarana mencapai ridha Illahi, maka dakwah berperan sebagai jantung sekaligus denyut nadinya.

Di dalam kehidupan di tengah masyarakat, dakwah seringkali diartikan menyampaikan pesan di hadapan layak yang dilakukan oleh ulama semata; bentuk dakwah hanya ceramah agama; dan mitra dakwah selalu terdiri banyak orang. Namun, pemahaman yang telah diterima secara umum oleh masyarakat tersebut tidaklah tepat sehingga masyarakat khususnya tiap diri muslim perlu menyadari bahwa mereka harus menjadi agent baik sebagai mitra dakwah maupun pedakwah walaupun mereka memiliki latar belakang yang beragam. Setiap diri muslim dapat menjadi agent karena dakwah dapat menggunakan bahasa verbal seperti yang biasa dilakukan oleh para da'i maupun dengan bahasa nonverbal yaitu berdakwah dengan tanpa kata-kata tetapi dengan menggunakan bahasa tubuh.

\section{Pembahasan}

\section{Definisi Dakwah}

Dakwah secara etimologis (bahasa) berarti memanggil, meminta tolong, mengundang, atau permohonan karena kata da'wah tersebut mempunyai tiga huruf asal, yaitu ، عdan و yang ketiga huruf tersebut

${ }^{1}$ Moh. Ali Aziz, Ilmu Dakwah, (Jakarta: Kenvana, 2009), h. 3. 
Rahma Dini Warastuti, Fenomena Penggunaan Bahasa....

membentuk beberapa kata dengan ragam makna. ${ }^{2}$ Dakwah adalah kegiatan yang bersifat menyeru, mengajak dan memanggil orang untuk beriman dan taat kepada Allah SWT sesuai dengan garis aqidah, syari'at dan akhlak Islam. Di dalam Alqurān, kata dakwah berbentuk fi'il (kata kerja) dan masdar (kata benda) muncul sebanyak 212 kali. ${ }^{3}$ Adapun menurut shara' (istilah), dakwah memiliki beberapa definisi. M. Quraish Shihab mendefinisikan dakwah, yaitu seruan atau ajakan kepada keinsafan, atau usaha mengubah situasi kepada situasi yang lebih baik dan sempurna, baik terhadap pribadi maupun masyarakat, ${ }^{4}$ sedangkan M. Canard dalam The Encyclopedia of Islam mengungkapkan, "In the religious sense, the da'wa is the invitation, addressed to men by God and the prophets, to believe in the true religion, Islam", (dalam pengertian keagamaan, dakwah adalah undangan Allah dan rasul yang ditujukan kepada umat manusia untuk beriman kepada agama yan benar, yaitu Islam). Jadi, pengertian dakwah pada hakikatnya adalah mengajak manusia kepada Allah dengan hikmah dan nasihat yang baik, sehingga mereka meninggalkan täghüt dan beriman kepada Allah agar mereka keluar dari kegelapan menuju cahaya Islam, Seperti yang Allah firmankan dalam Alqurān surah Annahl (16): 125;

"Serulah (manusia) kepada jalan Tuhanmu dengan hikmah, dan pengajaran yang baik, dan berdebatlah dengan cara yang baik. Sesungguhnya Tuhanmu, Dialah yang lebih mengetahui siapa yang sesat dari Jalan-Nya dan Dialah yang lebih mengetahui siapa yang mendapat petunjuk." 6

${ }^{2}$ Ahmad Warson Munawwir, Al Munawwir kamus Arab-Indonesia, (Surabaya: Pustaka Progresif, 1997), h.406. 2002), h.40.

${ }^{3}$ Asep Muhidin, Dakwah dalam Perspektif Alqurān, (Bandung: Pustaka Setia,

${ }^{4}$ M. Qurais Shihab, Membumikan al-quran, Fungsi dan Peran Wahyu dalam Kehidupan Masyarakat, (Cet.VII; Bandung: Mizan, 1994), h.194

5 M. Canard, "Da'wa", The Encyclopedia of Islam, B.lewis (et.al) Vol.II, (Leiden: E.J.Brill, 1991), h. 168-170.

${ }^{6}$ Kementerian Agama RI, Alqurān dan Terjemahnya, (Bandung: Fokus Media, 2010), h. 281 


\section{Urgensi dan Tantangan Dakwah}

Kewajiban dakwah ada pada setiap diri umat Islam tanpa terkecuali. Umat Islam, sesuai dengan kapasitas dan kemampuannya, dituntut untuk melakukan dakwah di mana pun ia berada. Dakwah tidak hanya terbatas di atas mimbar masjid atau mushalla saja tetapi di sekolah, pasar, stasiun, terminal dan semua tempat adalah medan dakwah. Seorang dosen maupun guru berdakwah mengajak taupun memberi contoh para muridnya agar rajin menuntut ilmu dan hidup di jalan Allah SWT. Seorang pedagang dapat berdakwah dengan menerapkan prinsip-prinsip Islam dalam berdagang. Seorang pejabat negara dapat berdakwah dengan menerapkan nilai dan moral Islam dalam mengelola negara dan seorang tokoh masyarkat menghimbau masyarakat untuk mentaati norma-norma agama. Dengan kata lain, semua orang bisa dan harus berdakwah sesuai dengan kapasitas dan kemampuannya, abik dengan bahasa verbal maupun nonverbal. Berdakwah adalah syariat yang diajarkan dan hukumnya fardhu kifayah. ${ }^{7}$ Perintah ini tidak boleh diabaikan, diacuhkan, dan dikurangi bobot kewajibannya karena terdapat banyak perintah dalam Alqurān dan sunnah Rasulullah untuk berdakwah dan amar ma'r-f nahi mungkār. Dakwah artinya mengumpulkan manusia dalam kebaikan dan menunjukan mereka kepada jalan yang benar dengan cara amar ma'ruf nahi munkār. Sandaran dari pendapat ini merujuk pada firman Allah SWT (QS Ali Imrān: 104) yang berbunyi, "Dan hendaklah ada di antara kamu segolongan umat yang mengajak kepada kebaikan, menyuruh kepada yang ma'ruf dan mencegah dari yang mungkar, mereka itulah orang-orang yang beruntung". 8

Selain itu, dakwah adalah sesuatu yang urgensi karena banyak tantangan yang akan selalu menghadang umat Islam, misalnya tantangan di era globalisasi ini. Di era globalisasi dengan makin 2013), h.7.

${ }^{7}$ Bahtar, Ilmu Dakwah; Paradigma untuk Aksi, (Palu: Sulteng Center Press,

\footnotetext{
${ }^{8}$ Kementerian Agama RI, Alqurān..., h. 63
} 
Rahma Dini Warastuti, Fenomena Penggunaan Bahasa....

berkembangnya ilmu pengetahuan dan teknologi, tantangan yang dihadapi semakin rumit. Tantangan tersebut tidak mengenal ruang, batas, waktu dan lapisan masyarakat, melainkan ke seluruh sektor kehidupan dan hajat hidup manusia, termasuk agama. Artinya, kehidupan umat Islam di mana pun ia berada akan menghadapi tantangan yang sama. Meskipun diakui bahwa di satu sisi kemajuan IPTEK menciptakan fasilitas yang membantu bagi pengembangan dakwah, namun kemajuan IPTEK justru menjadi tantangan. Tantangan dakwah yang amat kompleks dewasa ini dapat dilihat dari minimal dari tiga perspektif, yaitu:

Pertama, perspektif perilaku (behaviouristic perspective). Salah satu tujuan dakwah adalah terjadinya perubahan perilaku (behaviour change) pada masyarakat yang menjadi obyek dakwah kepada perubahan perilaku yang lebih baik. Kedua, tantangan dakwah dalam perspektif transmisi (transmissional perspective). Dakwah merupakan proses penyampaian atau transmisi ajaran agama Islam dari da $i$ sebagai sumber kepada mad'ū sebagai penerima. Ketika ajaran agama ditransmisikan kepada masyarakat yang menjadi obyek, maka peranan media sangat menentukan.

Ketiga, tantangan dakwah perspektif interaksi. Ketika dakwah dilihat sebagai bentuk komunikasi yang khas (komunikasi Islami), maka dengan sendirinya interaksi sosial akan terjadi. ${ }^{9}$ Di dalam interaksi sosial, terbentuk norma-norma tertentu sesuai pesan-pesan dakwah. Yang menjadi tantangan dakwah adalah bahwa masyarakat yang menjadi obyek dakwah pasti berinteraksi dengan masyarakat sekitar lainnya yang belum tentu membawa pesan yang baik, bahkan mungkin sebaliknya.

Berkaitan dengan dampak globalisasi pada tatanan kehidupan masyarakat, maka dibutuhkan metode dakwah yang tepat. Metode berarti rangkaian yang sistematis dan merujuk kepada tata cara yang

${ }_{9}^{9}$ Malik Idris, Strategi Dakwah Kontemporer, Cet. I; Makassar: Sawah Press, 2007), h.111. 


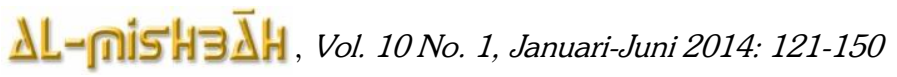

sudah dibina berdasarkan rencana yang pasti, mapan, dan logis. ${ }^{10}$ Dalam melaksanakan suatu kegiatan dakwah diperlukan metode penyampaian yang tepat agar tujuan dakwah tercapai. Metode dalam kegiatan dakwah adalah suatu rencana yang tersusun dan teratur yang berhubungan dengan cara penyajian. Untuk mendapatkan gambaran tentang prinsip-prinsip metode dakwah harus mencermati firman Allah S.W.T, dan Hadits Nabi Muhammad SAW :

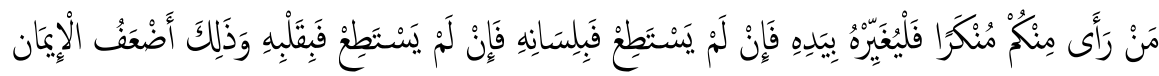

"Siapa di antara kamu melihat kemungkaran, ubahlah dengan tangannya, jika tidak mampu, ubahlah dengan lisannya, jika tidak mampu, ubahlah dengan hatinya, dan yang terakhir inilah selemah-lemah iman". [H.R. Muslim]. ${ }^{11}$

Allah Ta'ala berfirman dalam Surah Annahl (16) ayat 125 sebagaimana disebutkan pada halaman sebelumnya yang agar berdakwah dengan metode; hikmah, dan pengajaran yang baik, dan berdebatlah dengan cara yang baik ${ }^{12}$ yang akan diuraikan sebagai berikut:

\section{Dakwah Bil Hikmah}

Dakwah bil Hikmah yakni menyampaikan dakwah dengan cara yang arif bijaksana, yaitu melakukan pendekatan sedemikian rupa sehingga pihak obyek dakwah mampu melaksanakan dakwah atas kemauannya sendiri, tidak merasa ada paksaan, tekanan maupun konflik. Dengan kata lain, artinya dakwah memberikan "contoh yang baik", yang di dalamnya bisa berupa tingkah laku atau tutur kata yang baik. Jika tingkah laku dan tutur kata itu diteladani, bisa menyentuh dan mengubah sikap orang lain, berarti di dalam terdapat hikmah. ${ }^{13}$

${ }^{10}$ Onong Uchjana Effendi, Ilmu, Teori dan Filsafat Komunikasi, (Cet. II; Bandung: PT. Citra Aditya Bakti, 2000), h.9

${ }^{11}$ Muslim bin al-Hajjāj al-Qushairi, Sahịh Muslim; Bāb al-Imān, (Cet. 1; Beirut: Dar al-Fikr, 2003), h. 52

${ }^{12}$ Lihat, Kementerian Agama RI, Alqurān..., h. 281

${ }^{13}$ M. Munir, Metode Dakwah, Edisi Revisi, (Cet III; Jakarta: Kencana, 2006), h. $12-13$ 
Rahma Dini Warastuti, Fenomena Penggunaan Bahasa....

Dakwah dengan hikmah jauh lebih efektif; tantangannya sedikit, tetapi dampaknya sangat besar. Kebanyakan orang lebih senang meneladani suatu kebajikan atas dasar kesadaran diri daripada dipaksakan oleh orang lain. Biarlah masyarakat melihat, menghayati, dan mengikuti prilaku baik itu. Dakwah bil hikmah atau contoh yang baik bisa direalisasikan dengan budi pekerti yang baik (akhlaq karimah). Kekuatan akhlak mulia dalam menarik simpati masyarakat untuk menerima dakwah sangatlah besar. Telah banyak bukti sejarah yang membenarkan hal itu, mulai sejak zaman Rasulullah SAW hingga zaman ini. Rasulullah SAW mencontohkan cara berdakwah dengan hikmah yaitu dengan tidak marah saat seorang kaum musyrik meludahi beliau setiap pergi ke masjid. Suatu hari, ketika Rasulullah SAW pergi ke masjid, beliau merasakan keanehan karena orang yang setiap saat meludahi beliau setiap akan pergi ke masjid tidak ada. Sesampainya di masjid Rasulullah SAW menanyakan kepada para sahabat di mana orang itu berada. Lalu Rasulullah SAW memperoleh jawaban bahwa orang yang meludahi beliau jatuh sakit. Setelah mendengar jawaban itu, Rasulullah datang membesuk orang tersebut dan mendoakan kesembuhan baginya. Akhirnya, orang tersebut kemudian menyatakan diri sebagai Muslim.

Contoh lain keluhuran perilaku Rasulullah adalah kisah seorang pengemis Yahudi buta di pojok pasar Madinah yang selalu menjelekjelekkan Rasulullah SAW. Setelah Rasulllah SAW meninggal dunia, Abu Bakar ash-Shiddiq mengunjungi Aisyah, anaknya yang juga isteri Rasulullah SAW. Sesampainya di rumah Aisyah, Abu Bakar bertanya kepada anaknya apa sunnah Rasulullah yang belum dikerjakan olehnya. Aisyah menjawab bahwa Rasulullah SAW setiap memberi makan pengemis Yahudi buta di pasar Madinah. Abu Bakar pun bergegas menuju pasar Madinah menemui orang Yahudi tersebut yang tak hentihentinya menjelek-jelekkan Rasulullah SAW. Namun, karena ingin mengukuti sunnah Rasulullah SAW, Abu Bakar tetap memberi makan Yahudi buta tersebut dengan cara menyuapinya. Namun alangkah kaget Abu Bakar karena saat menyuapi Yahudi tersebut berkata, "Siapa 


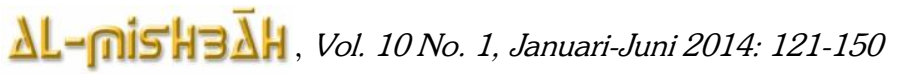

kamu? Orang yang biasa menyuapiku makan tiap hari terlebih dahulu melembutkan makanan sehingga mulutku tidak perlu mengunyah makanan". Kemudian Abu Bakar berkata kepada pengemis Yahudi buta itu bahwa orang yang bisa memberinya makan tiap hari telah tiada. Abu Bakar juga mengatakan bahwa orang yang biasa memberinya makan tiap hari adalah Rasulullah SAW. Betapa terkejut Yahudinya tersebut mengetahui bahwa orang yang menyuapinya adalah Rasulullah SAW; orang yang setiap hari dijelek-jelekkannya. Akhirnya pengemis Yahudi buta itu masuk Islam.

Dua peristiwa di atas adalah sekelumit contoh bagaimana ampuhnya akhlak mulia menarik minat seseorang untuk hidup di bawah naungan ajaran Islam melalui dakwah bil hikmah

\section{Dakwah Bil Mau'ihatul Hasanah}

Dakwah Bil Mau'ihatul Hasanah adalah memberikan nasihat yang baik kepada orang lain dengan cara yang baik, yaitu petunjukpetunjuk ke arah kebaikan dengan bahasa yang baik, dapat diterima, berkenan dihati,lurus pikiran sehingga pihak yang menjadi objek dakwah dengan rela hati dan atas kesadarannya sendiri dapat mengikuti ajaran yang disampaikan. Jadi dakwah bukan propaganda, ${ }^{14}$ sedangkan menurut Ali Musthafa Ya'kub dalam Sejarah dan Metode Dakwah Nabi dikatakan bahwa mau'ihah hasanah adalah ucapan yang berisi nasihat yang baik dan bermanfaat bagi orang yang mendengarkannya, atau argumen-argumen yang memuaskan sehingga pihak audiensi dapat membenarkan apa yang disampaikan oleh subjek dakwah. ${ }^{15}$ Seorang da'i harus mampu mengukur tingkat intelektualitas objek dakwahnya, sehingga apa yang disampaikan mampu diterima dan dicerna dengan baik serta ajaran-ajaran Islam yang merupakan materi dakwah dapat teraplikasi didalam keseharian masyarakat. Hal ini sesuai dengan pesan

${ }^{14}$ Siti Muriah, Metode Dakwah Kontemporer, (Yogyakarta: Mitra Pustaka, 2000), h. 43-44

${ }^{15}$ Ali Musthafa Ya'kub, Sejarah Dan Metode Dakwah Nabi, (Jakarta: Pustaka Firdaus, 1997), h. 21 
Rahma Dini Warastuti, Fenomena Penggunaan Bahasa....

Ali ra. Dalam sebuah riwayat: Ali berkata, "Berbicaralah dengan orangorang sesuai dengan apa yang telah mereka ketahui. Apakah kau suka bila mereka mendustakan Allah dan Rasul-Nya?"16

Pepatah Arab menyatakan "attariqatu ahammu minal maddah" (cara atau metode penyampaian lebih penting dari subtansi yang disampaikan). ${ }^{17}$ Kata mutiara ini mengajarkan bahwa metode atau cara dalam menyampaikan sesuatu lebih penting dari substansi yang disampaikan. Misalnya, dakwah dalam bentuk nasihat yang baik jika disampaikan dengan perkataan yang menyakitkan hati atau menyinggung harga diri cenderung akan ditolak. Alih-alih menyadarkan seseorang akan kesalahan yang dilakukannya, nasihat yang disampaikan dengan perkataan yang menyakitkan akan menimbulkan perasaan tidak senang, bahkan menimbulkan sikap bermusuhan.

Begitu juga dengan penggunaan kekerasan dalam dakwah. Metode ini tidak akan mencapai tujuan dakwah. Bahkan penggunaan kekerasan dalam berdakwah kontraproduktif bagi tercapainya tujuan dakwah. Medote kekerasan dalam berdakwah bukannya membuat masyarakat semakin bersimpati terhadap Islam, tapi malah membuat masyarakat takut pada Islam (islamophobia) dan menjauhi Islam.

Jika para pendakwah berdakwah dengan cara yang kasar, maka mereka akan dijauhi oleh masyarakat. Mereka seharusnya menghiasi diri mereka dengan keramahan, bersabar dari derita serta berkata-kata dengan lemah-lembut di mana saja sehingga dapat menambah orang yang mengikuti kebaikan dan menipiskan pelaku kejahatan, lalu orangorang mendapatkan manfaat dari dakwah tersebut dan menerimanya. Dalam sebuah hadits Rasulullah SAW menghimbau umat Islam untuk senantiasa berlaku lemah-lembut dalam hal apa saja karena kebajikan diharamkan bagi orang yang tidak memiliki sifat lemah-lembut. Sabda

\footnotetext{
${ }^{16}$ Muhammad bin Ismā'il al-Bukhari, al-Jami’ al-Sahih, Juz I, Bāb Kitāb al-'Ilm (Kairo: Matba'ah al-Salafiyyah, Cet. I, 1400 H.), h. 62.

${ }^{17}$ Ali Azis, Ilmu...., h. 345
} 


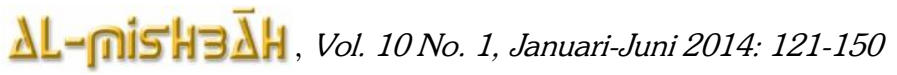

Rasulullah SAW, "Barang siapa yang tidak memiliki kelemah-lembutan, maka diharamkan seluruh kebaikan bagi dirinya,"(HR Muslim). ${ }^{18}$

\section{Dakwah Bil Mujādalah Bil lati Hia Ahsan}

Metode ini merupakan cara yang digunakan untuk berdakwah dengan orang-orang yang memiliki daya intelektualitas dan cara berpikir yang maju. Metode ini berupa tukar pendapat yang dilakukan oleh dua belah pihak secara sinergis, yang tidak melahirkan permusuhan dengan tujuan agar lawan menerima pendapat yang diajukan dengan memberikan argumentasi dan bukti yang kuat. Antara satu dengan yang lainnya saling menghargai Dan menghormati pendapat keduanya berpegang kepada kebenaran, mengakui kebenaran pihak lain dan ikhlas menerima hukuman kebenaran tersebut. ${ }^{19}$ Metode seperti ini juga digunakan untuk berdakwah dengan ahli kitab. Oleh karena itu, Alquran juga memberi perhatian khusus tentang berdakwah dengan ahli kitab karena mereka memang telah dibekali pemahaman keagamaan dari utusan terdahulu. Alqurān dalam QS. Alankabūt (29): 46 juga melarang berdebat dengan mereka kecuali dengan jalan yang baik, "Dan janganlah kamu berdebat dengan Ahli Kitab (Yahudi dan Nasrani) melainkan dengan cara yang baik. Kecuali dengan orang-orang yang zhalim diantara mereka" ${ }^{20}$

Berbekal ayat tersebut, kaum muslim dilarang berdebat dengan ahli kitab kecuali dengan cara yang baik, sopan santun, lemah lembut dan menunjukkan ketinggian budi ummat Islam kecuali jika mereka menampakkan keangkuhan dan kezhaliman.

Ketiga metode tersebut diaplikasikan secara operasional dengan cara sebagai berikut:

${ }^{18}$ Muslim bin al-Hajjāj al-Qushairi al-Naisaburì, Sahih Muslim, Bāb Fadl al-Rifq (Beirut: Dār al-Fikr, 2003), h. 1280.

${ }^{19}$ Munir, Metode.

${ }^{20}$ Kementerian Agama RI, Alqurān..., h. 402 
Rahma Dini Warastuti, Fenomena Penggunaan Bahasa....

a) Dakwah bil kitābah yaitu berupa buku, majalah, surat, surat kabar, spanduk, pamflet, lukisan-lukisan dan sebagainya. ${ }^{21}$

b) Dakwah bil lisān, meliputi ceramah, seminar, simposium, diskusi, khutbah, saresehan, brain storming, obrolan, dan sebagainya. ${ }^{22}$ Metode dakwah dengan lisan atau bil lisān, maksudnya adalah penyampaian informasi atau pesan dakwah melalui lisan (ceramah atau komunikasi langsung antara subyek dan obyek dakwah) dengan kata-kata yang lemah lembut, yang dapat difahami oleh mad'ú (obyek dakwah), bukan dengan kata-kata yang keras dan menyakitkan hati.

c) Dakwah bil-häl, yaitu berupa perilaku yang sopan sesuai ajaran Islam, memelihara lingkungan, dan lain sebagainya. ${ }^{23}$

Demi meraih keberhasilan dakwah di era global, maka setiap diri muslim perlu memiliki profil berikut ini, yaitu: komitmen tauhid, istiqamah, jujur, dan memiliki visi yang jelas, wawasan ke-Islam-an, keterampilan memadukan antara dakwah bil kitābah, bil lisān dengan dakwah bil hàl, sesuai kata dengan perbuatan, berpikir strategis, memiliki kemampuan analisis interdisipliner, sanggup berbicara sesuai dengan kemampuan masyarakat. ${ }^{24}$

\section{Profesi dan Metode Dakwah}

Untuk mencapai tujuan dakwah, maka sangat perlu memperhatikan pemilihan metode dakwah. Metode dakwah yang sangat sering digunakan adalah metode lisan. Metode lisan ini biasanya dalam bentuk ceramah, obrolan maupun diskusi. Jika metode lisan ini membutuhkan dihadiri oleh khalayak ramai, maka metode yang sering

${ }^{21}$ Wardi Bahtiar, Metodologi Penelitian Ilmu Dakwah, (Cet. I; Jakarta: Logos Wacana Ilmu, 1997), h. 34

${ }^{22}$ Ibid.

23 Ibid.

${ }^{24}$ Syahrin Harahap, Islam dan Implementasi Pemberdayaan, (Cet. I, Yogyakarta: PT. Tiara Wacana, 1999). h. 130 


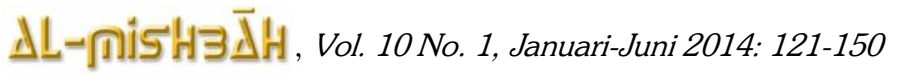

digunakan adalah dalam bentuk ceramah, dan jika metode ini dilaksanakan dengan frekuensi yang tinggi, maka dakwah ini biasanya dilakukan oleh seorang yang ber 'profesi' da'i. Namun demikian, setiap orang dapat berdakwah lisan (bahasa verbal) maupun dengan bahasa nonverbal dengan metode, durasi dan frekuensi yang beragam disesuaikan dengan kemampuan atau bahkan profesi yang dimiliki. Pentingnya berdakwah disebabkan keadaan dunia saat ini sudah jauh lebih berkembang dan alur masuknya informasi begitu cepat. Maka hal tersebut pun berdampak kepada cara berdakwah. Imam Hasan Al Banna pernah berkata.

"Sarana-sarana propaganda saat ini tidak seperti dahulu yang hanya melalui khutbah-khutbah, ceramah-ceramah, pertemuan, ataupun surat-menyurat. Tetapi saat ini, seruan itu disebarkan melalui majalah, koran, film, panggung teater, radio dan media lain yang beragam. Sarana-sarana itu telah berhasil menembus semua jalan menuju akal dan hati khalayak, baik pria maupun wanita, di rumah-rumah, di toko-toko, di pabrik-pabrik, bahkan di sawah-sawah mereka. Maka adalah wajib bagi para pengemban misi dakwah ini untuk juga menguasai semua sarana tersebut agar dakwah mereka membuahkan hasil yang memuaskan." 25

Apabila diperhatikan, benar adanya ucapan Imam Hasan Al Banna di atas. Untuk mencapai kesuksesan dakwah saat ini, para kader dakwah harus menguasai semua bidang yang ada. Dari politik, kesehatan, perdagangan, perekonomian, media massa, bahkan sampai bidang kesenian. Oleh karena itu, ternyata begitu banyak bidang yang harus dikuasai oleh ummat Islam untuk mensukseskan dakwah ini di mana dakwah ini berorientasi untuk menggunakan segenap sumber daya berupa disiplin ilmu yang bertujuan untuk kemaslahatan ummat. Namun, bidang-bidang ilmu tersebut tentu akan sulit dikuasai hanya oleh segelintir orang saja, demi kesuksesan dakwah ini, perlu dibentuk gerakan dakwah yang berorientasi pada minat dan bakat dari setiap orang terhadap profesinya. Untuk mewujudkannya, setiap diri muslim dengan berbagai latar belakang profesi, bersama-sama berdakwah

${ }^{25}$ Risalah Dakwah Ikhwan...., h. 2 
walaupun dengan beragam metode dan situasinya. Dakwah profesi ini sangat penting, dikarenakan setiap profesi pastinya akan terjun langsung ke masyarakat, entah itu dengan cara menggunakan pendekatan ruhaniah seperti seorang ustadz, menggunakan pendekatan politik dan kenegaraan seperti politikus dan anggota dewan, menggunakan pendekatan kesehatan seperti yang dilakukan dokter dan tenaga kesehatan lain, menggunakan pendekatan media dan jurnalistik seperti yang sering dilakukan oleh wartawan atau penulis, ataupun dengan cara lain tergantung dari profesi, minat dan bakat setiap orang tersebut. Dengan menggunakan orientasi profesi, maka seruan dakwah bisa mengalir ke setiap aliran disiplin ilmu hingga mencapai tujuan kita, yaitu masyarakat yang islami.

Untuk menjalankan dakwah profesi ini, perlu suatu langkah yang tertata dan teratur agar dakwah ini tidak putus di tengah jalan. Di bawah ini beberapa macam profesi yang dimiliki seseorang namun profesi tersebut tidak menghalangi kegiatan dakwah, justru profesi yang dimiliki seseorang akan membantu aktifitas dakwahnya walaupun menggunakan bahasa nonverbal ${ }^{26}$ dan dengan pendekatan yang berbeda.

\section{Dakwah Seorang Dosen}

Seseorang yang berprofesi seorang dosen dapat memulai dakwahnya di kampus. Dalam tahap awal, pusat perubahan dimulai di wilayah ilmiyah, yaitu kampus-kampus dan sekolah-sekolah atau biasa disebut dengan amal tullābi, kemudian langkah berikutnya adalah mengakses wilayah masyarakat umum atau amal mihani. Idealnya, amal tulläbi dan amal mihani itu harus sinergi, karena berlatih berdakwah harus dimulai sejak masa mahasiswa. Karena dosen merupakan public

\footnotetext{
${ }^{26}$ Komunikasi nonverbal adalah proses komunikasi dimana pesan disampaikan tidak menggunakan kata-kata. Contoh komunikasi nonverbal ialah menggunakan gerak isyarat, bahasa tubuh, ekspresi wajah dan kontak mata, penggunaan objek seperti pakaian, potongan rambut, dan sebagainya, simbol-simbol, serta cara berbicara seperti intonasi, penekanan, kualitas suara, gaya emosi, dan gaya berbicara.http://id.wikipedia. org/wiki/Komunikasi_nonverbal, diakses 3 Mei 2014.
} 


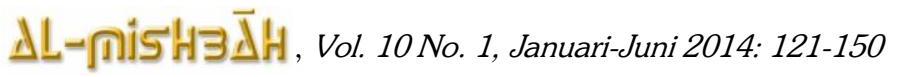

figure di kalangan para mahasiswa, maka posisi ini sangat efektif untuk berdakwah baik secara lisan, tulisan maupun teladan. Berikut ini adalah kisah dakwah seorang dosen yang di Fakultas Tarbiyah Universitas AlAzhar yang berasal dari Ar-Roml, Alexandria. Almarhum syahid pada peristiwa pembantaian Monumen Anwar Sadat pada tanggal 27 juli 2013. Beliau merupakan seorang Hafizh Qurān dan turut serta dalam aksi revolusi 25 Januari. ${ }^{27}$ Seorang teman dosen ini mengatakan;

"Sungguh aku tidak mengenalnya melainkan ia gemar mengkhatamkan Alqurān, mengajarkan Alqurān. Aku sering melihat dia suka tersenyum, dan tidaklah ia gemar menasehati kecuali karena Allah, aku bersaksi dihadapan Allah bahwa dia turut juga dalam membantu revolusi Libiya, berjuang di Gazza, namun belum berkesempatan ke Syria dengan niat mencari kemulyaan syahid, namun ia diberikan Allah di sini di negeri Mesir. Ya Allah terimalah amalan syahidnya!"28

Dari kisah ini dapat diambil ibrahnya bahwa dakwah tidak selamanya dalam bentuk ceramah maupun diskusi, tetapi contoh yang baik juga merupakan amalan dakwah di mata Allah S.W.T. Amalan ibadah, kebaikan dan kesyahidan seorang dosen tersebut di dunia ini sangat membekas pada diri temannya dan perbuatannya tentu akan menjadi contoh bagi mahasiswanya dan orang-orang yang mengenalnya.

Kisah kedua adalah kisah seorang Dosen dari UIN Sunan Gunung Djati Bandung. Dosen ini masuk ke tempat pelacuran di daerah Bekasi dan mem-booking 8 PSK sekaligus, lalu ke-8 PSK tersebut diboyong ke satu kamar. mem-booking mereka. Sang Dosen tersebut berbicara dan menasehati para PSK tersebut selama 2 jam tentang dosa dan akbibat berbuatan yang mereka lakukan. Sang dosen tersebut mengatakan;

${ }^{27}$ Muharrik Dakwah, Dr. Sayyid Ismail, Sang Dosen Hafidz Quran ini Syahid, http://www.muharrikdakwah.com/2014/04/dr-sayyid-ismail-sang-dosen-hafidz.html, diakses 3 Mei 2014

${ }^{28}$ Ibid. 
Rahma Dini Warastuti, Fenomena Penggunaan Bahasa....

"Bayangkan kalau anak perempuanmu seperti kamu mau nggak? Kalau anak-anakmu tahu kelakuanmu seperti ini mau gak?” "Kalau ibumu tahu mau gak? Bayangkan perasaan mereka, betapa malu dan sakit hatinya. Inikah balasan pada ibumu yang sudah susah payah melahirkan, membesarkan dan mendidikmu,....?" 29

Akhirnya 8 PSK itu menangis, menyadari, menyesali, dan tobat seketika, serta berjanji bahwa esok harinya mereka tidak bekerja lagi sebagai PSK. Esoknya, sang dosen datang lagi mengecek, dan ternyata benar, 8 nama itu sudah tidak terdaftar sebagai PSK. Beberapa hari kemudian, sang dosen mengunjungi ke-8 orang itu ke kampungnya masing-masing, mengontrol dan membina, dan komunikasi terus berjalan setelah beberapa minggu/bulan.. Ke delapan perempuan muda tersebut, kini ada yang buka warung, buka kios, kerja di pabrik dll. Pada salah satu yang jualan gorengan, sang dosen ustadz berkata, "Naah ... begituu ... ini yang halal dan barokah. Rizki halal tidak susah asalkan dicari." Mereka merasakan kebahagiaan yang sangat amat telah keluar dari jerat pekerjaaan kotornya. ${ }^{30}$

Fenomena gaya berdakwah tiap diri seorang muslim saat ini semakin beragam. Dosen dari UIN tersebut sangat memahami karakter dan kondisi mad'u-nya. Oleh karena itu, dosen tersebut menggunakan bahasa informal ketika sedang berdakwah dengan ke delapan PSK tersebut dan untuk memastikan dakwah ini berhasil, maka dosen tersebut melakukan follow-up setelah dakwah dilakukan

\section{Dakwah para Insinyur}

Kisah dakwah para insinyur ini terjadi di Mesir yang dimulai dari lembaga profesi teknik (persatuan insinyur). Mereka tidak hanya bekerja pada bidang teknik, tetapi juga membuat RUU dan advokasi keteknikan yang bernuansa Islam. Karena para aktivis dakwah aktif terlibat di

${ }^{29}$ Moeflich Hasbullah, "Kisah Dosen UIN Mem-booking 8 PSK dalam Satu Kamar", http://moeflich.wordpress.com/2012/07/02/kisah-dosen-uin-mem-booking8-psk-dalam-satu-kamar/, diakses 2 Mei 2014

${ }^{30}$ Ibid. 


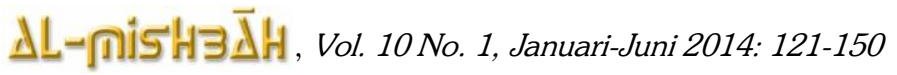

lembaga profesi tersebut, maka mereka memiliki kesempatan untuk mewarnai lembaga tersebut. Akhirnya lembaga profesi itu bertindak seperti partai politik dan pressure groups terhadap pemerintah. Karena aktivis mewarnai dan menguasai banyak lembaga profesi, maka seakanakan mereka yang mengontrol pemerintah dengan kebijakan dasar yang sama. Karena pemerintah Mesir menyadari hal itu, maka lembagalembaga profesi akan dibredel. Rencana ini sulit terlaksana karena terkait dengan institusi negara, infrastruktur dan suprastruktur politik, dan jika pembaga profesi ini dibubarkan sangat tidak mungkin karena bertentangan dengan UU dan tentu akan terbentuk lembaga yang baru lagi. Jika pemerintah menutup kantornya, maka pemerintah akan dituntut lewat pengadilan. Hampir di setiap lembaga profesi di Mesir, pasti ada aktifis dakwah di dalamnya, dan kondisi ini sangat mengkhawatirkan bagi pemerintah. Dan pemerintah tidak mampu berbuat banyak, karena jika para aktivisnya ditangkap dan dipenjarakan, maka industri dan pelayanan jasa (terutama rumah sakit, konsultan proyek, dan pengacara) akan mengeluh, karena tidak ada tenaga ahlinya dan akhirnya tidak bisa berjalan. Maka, proses pembangunan pun bisa terhambat. ${ }^{31}$

\section{Dakwah Para Ahli Komputer}

Di Mesir, terdapat suatu kelompok elit yang dinamai 'Salsabil'. Kelompok ini mampu membuat perusahaan komputer dan berkembang dan akhirnya mampu mengikuti tender penyediaan software di Departemen Pertahanan Mesir. Kelompok elit ini akhirnya menang dalam tender karena mampu menawarkan harga murah dan menawarkan kualitas paling baik. Setelah pejabat militer menyadari bahwa perusahaan tersebut milik aktivis dakwah, maka mereka ketakutan dan menggerebek serta menyegel kantornya. Peristiwa tersebut menjadi berita besar, karena secara beramai-ramai lembaga

\footnotetext{
${ }^{31}$ Dakwatuna.com, "Peran Pemuda dalam Gerakan Dakwah" http://www.dakwatuna.com/2007/10/18/286/peran-pemuda-dalam-gerakandakwah, diakses 2 Mei 2014
} 
Rahma Dini Warastuti, Fenomena Penggunaan Bahasa....

profesi di Mesir bersuara, mulai dari lembaga profesi teknik, komputer, pengacara dan lainnya, hingga akhirnya dibebaskan dan dibuka kembali. $^{32}$

\section{Dakwah Para Dokter}

Selain lembaga profesi lainnya, para dokter di Mesir beramairamai menggelar acara munasharah untuk kasus Bosnia sampai terkumpul dana sebesar US\$ 4 juta, tetapi pemerintah melarang kegiatan tersebut. Akhirnya kasus tersebut menjadi berita besar karena dibela oleh lembaga profesi kedokteran, keperawatan, pengacara dan sebagainya. Kemudian kasus tersebut dibawa ke pengadilan dan akhirnya dinyatakan menang, walaupun dananya terpaksa dibagi dua (fifty-fifty) untuk lembaga pemerintah dan lembaga dakwah. ${ }^{33}$

\section{Dakwah Sang Orang Tua}

Berdakwah merupakan kewajiban yang Allah azza wajalla bebankan kepada siapa saja yang memiliki ilmu tentang Alqurān dan Assunnah dengan pemahaman yang benar. Allah yang memikulkan ikatan perjanjian yang kuat di atas pundak-pundak setiap diri muslim untuk menyampaikan ilmunya kepada manusia lainnya secara umum dan tidak menyembunyikannya. Sebagaimana Allah firmankan dalam Alqurān (QS. Ali Imrān [3]: 187) yang artinya: "Dan (ingatlah), ketika Allah mengambil janji dari orang-orang yang telah diberi kitab (yaitu): "Hendaklah kamu menerangkan isi kitab itu kepada manusia, dan jangan kamu menyembunyikannya" ${ }^{34}$

Dalam ayat di atas dapat diambil hikmah tentang etika dakwah yang dapat diaplikasikan dalam pendidikan terhadap anak, karena di dalam sebuah keluarga, mendidik anak juga merupakan sebuah ladang dakwah. Bahwasanya, orang tua, selain mendidik dengan pemberian

\footnotetext{
32 Ibid.

33 Ibid.

${ }^{34}$ Kementerian Agama RI, Alqurān...., h. 75
} 


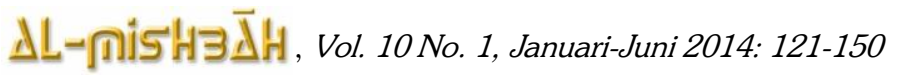

perintah, orang tua juga harus memberikan pendidikan tersebut dengan pemberian contoh. Misalnya, jika seorang ayah menyuruh anaknya untuk sholat berjamah di masjid, maka ayah tersebut setidaknya memberikan contoh dengan mengajaknya ke masjid dan selanjutnya dibentuk suatu rutinitas akan amalan tersebut. Dengan terus melakukan ajakan dan pemberian contoh secara rutinitas, kemungkinan dakwah tersebut akan berhasil.

Berikut ini adalah kisah nyata masa muda Dr. Arun Gandhi (cucu dari Mahatma Gandhi - Pendiri Lembaga M.K.Gandhi) yang dididik oleh ayahnya tanpa kekerasan. Kisah ini bermula ketika Arun dan keluarganya tinggal di daerah terpencil sehingga jauh dari hingar bingar kota Durban, Afrika Selatan. Pada saat Arun berkempatan mengunjungi kota dengan ayahnya, maka kesempatan ini tidak disiasiakan olehnya untuk untuk memperbaiki mobil dan menonton bioskop sendirian dan ternyata Arun terpikat dengan permainan John wayne. Akhirnya Arun lupa dengan janji dengan ayahnya untuk bertemu dan bersama- sama pulang ke rumah pada pukul 5 sore. Dengan gelisah sang ayah bertanya pada Arun, "Kenapa kau terlambat?" Arun sangat malu untuk mengakui bahwa ia menonton film John Wayne, dan menjawab, "Tadi, mobilnya belum siap sehingga saya harus menunggu." Padahal, ternyata tanpa sepengetahuan Arun, sang ayah telah menelepon bengkel mobil itu dan sang ayah tahu bahwa arun telah berbohong. Kemudian sang ayah berkata, "Ada sesuatu yang salah dalam membesarkan kau sehingga kau tidak memiliki keberanian untuk menceritakan kebenaran pada ayah. Untuk menghukum kesalahan ayah ini, ayah akan pulang ke rumah dengan berjalan kaki sepanjang 18 mil dan memikirkannya baik-baik." Lalu, sang ayah dengan tetap mengenakan pakaian dan sepatunya mulai berjalan kaki pulang ke rumah. Padahal hari sudah gelap, sedangkan jalanan sama sekali tidak rata. Arun tidak sanggup meninggalkan ayahnya, maka selama lima setengah jam, Arun mengendarai mobil pelan-pelan di belakang ayahnya dan melihat penderitaan yang dialami oleh ayahnya hanya karena kebohongan bodoh yang ia lakukan. Sejak itu Arun tidak pernah 
akan berbohong lagi. Arun berkata, "Sering kali saya berpikir mengenai peristiwa ini dan merasa heran. Seandainya Ayah menghukum saya sebagaimana kita menghukum anak-anak kita, maka apakah saya akan mendapatkan sebuah pelajaran mengenai tanpa kekerasan? Saya kira tidak. Saya akan menderita atas hukuman itu dan melakukan hal yang sama lagi. Tetapi, hanya dengan satu tindakan tanpa kekerasan yang sangat luar biasa, sehingga saya merasa kejadian itu baru saja terjadi kemarin. Itulah kekuatan tanpa kekerasan." 35

Kisah di atas merupakan salah satu contoh metode dakwah dengan hikmah, bahwa ternyata tindakan mendidik tanpa kekerasan tersebut sangat mengena terhadap anaknya.

\section{Dakwah Sang Pengacara}

Fenomena dakwah terjadi di negara Turki tentang diperbolehkannya penggunaan jilbab. Di negara Turki, setelah para PNS wanita diperbolehkan berjilbab, kini pengadilan tinggi Turki mencabut larangan pemakaian jilbab bagi pengacara perempuan. Dengan aturan baru itu, pengacara muslimah memiliki hak mendaftar di Asosiasi Pengacara Turki (TBB) dengan foto mengenakan jilbab. Pihak pengadilan menyatakan bahwa pembatasan (hak) ini tidak bertentangan dengan semangat konstitusi, republik sekuler dan masyarakat demokrasi berdasarkan konstitusi. Isu ini mencuat setelah seorang pengacara berjilbab mengajukan gugatan karena mendapatkan diskriminasi atas agamanya saat mendaftar ke asosiasi. Dia diminta untuk menyerahkan foto tanpa mengenakan jilbab sesuai dengan dengan aturan di asosiasi. Pengadilan tinggi justru membalik aturan itu. Dengan mengutip konvensi konstitusi dan internasional di Turki, Dewan Majelis Negara ke Delapan menyatakan hak itu seharusnya tidak dibatasi aturan yang bertentangan dengan konstitusi. Menurut pengadilan, asosiasi pengacara melanggar hak untuk bekerja dan begitu juga dengan kebebasan

${ }^{35}$ Dikutip dari Ayah Edy, I Love U Ayah Bunda, ( Jakarta: PT Mizan Publika, 2009), h. 53. 


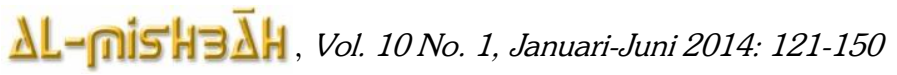

beragama. Pengadilan memutuskan foto pengacara dalam lisensinya wajib menunjukkan identitas mereka dan harus memudahkan mereka untuk dikenali. Akhirnya semua pengacara perempuan akan diizinkan memasang foto dalam kartu identitas mereka dengan mengenakan jilbab yang tidak menutupi wajah, dahi dan dagu.

Perlu diketahui bahwa sebelum keputusan tersebut dibuat, pengacara perempuan berjilbab di negara dengan mayoritas Muslim itu tidak diizinkan masuk ke pengadilan. Untuk pertama kalinya, pengacara berjilbab boleh menginjakkan kaki mereka di pengadilan Januari $2012 .{ }^{36}$

\section{Dakwah Seorang Pegawai Restoran}

Seorang pekerja yang bernama Muntako dari kota Semarang sudah lebih dari lima tahun tinggal di Inggris. Ia kurus kering karena berpuasa dengan khusuk walaupun ia harus bekerja siang dan malam. Di tengah masyarakat London, yang hidup mewah dan konsumtif dan di siang hari dengan bibirnya yang kering, ia berangkat bekerja dan baru pulang menjelang akhir waktu sahur. Ia bekerja sedemikian berat, karena ia ingin memberi kehidupan yang layak untuk keluarganya di tanah air, khususnya untuk masa depan pendidikan anak satu-satunya yang ia sebut sebagai titipan mulia Illahi dan juga karena berkeinginan membantu orang-orang tua, para janda, dan anak-anak usia sekolah yang terlantar di kampung halamannya. Usaha yang telah ia lakukan adalah membeli sebidang tanah yang dipersiapkan untuk panti asuhan yatim dan fakir miskin kelak ketika ia kembali ke tanah air. Ia yakin Allah akan membantunya. ${ }^{37}$

Ibrah yang bisa kita ambil dari kisah di atas adalah tentang tekad Pak Muntako untuk mendirikan panti asuhan yatim dan fakir miskin walaupun ia harus meninggalkan keluarganya ke luar negeri dalam waktu yang lama, Ia pernah menyemapaikan dengan mantapnya bahwa

${ }^{36}$ Bersama Dakwah, Alhamdulillah, Pengadilan Turki Cabut Larangan Jilbab bagi Pengacara, http://www.bersamadakwah.com /2013/11alhamdulillah-pengadilanturki-cabut.html, diakses 2 Mei 2014

${ }^{37}$ Ali Azis, Ilmu. h. 2 
Rahma Dini Warastuti, Fenomena Penggunaan Bahasa....

Tuhan itu Kaya, artinya Allah akan membantu umatnya yang menegakkan agama Allah.

\section{Dakwah Seorang yang Bertato}

Orang yang tertato ini bernama Yudo, Ia memiliki rambut panjang yang tinggal di Siwalankerto Surabaya, kebetulan tempatnya tidak jauh dari rumah seorang profesor bidang agama sekaligus pendakwah di beberapa negara, dan daerah di Indonesia. Yudo sangat fanatik dengan agama Islam yang dianutnya namun tidak pernah pergi ke masjid. Seminggu sekali ia mengumpulkan pemuda dan orang dewasa yang 'seirama', yaitu sama-sama pecinta lagu dangdut dan sama -sama tidak pernah ke masjid. Beberapa di antaranya tidak muslim. Mereka akrab dan riang dalam setiap kali berlatih musik dangdut. Suatu hari, Yudo meminta ijin ketua RT untuk menggunakan pos kamling untuk bakar ikan bersama menyambut malam Lailatul Qadar 27 Ramadhan. Sang profesor ini tidak mengetahui pesan apa yang disampaikan Yudo kepada kelompoknya pada malam itu. Ketika baru saja selesai menjadi imam shalat tarawih di Tokyo, profesor tersebut terkejut mendapat SMS / pesan pendek dari ketua RT, yang isinya menyebutkan bahwa ada dua orang masuk Islam di depan Yudo. Bahkan, ada beberapa orang bertato lainnya kemudian sesekali pergi ke masjid bersamanya. Pada akhirnya sang profesor tersebut mengatakan bahwa Yudo adalah pendakwah tanpa mimbar, ia melakukan dakwah 'ikan bakar' yang menyentuh hati kepada mereka yang bertahun-tahun tidak tersentuh oleh dakwah dalam bentuk ceramah. Sang profesor agama ini telah lebih sepuluh tahun berceramah di masjid setempat, tetapi belum pernah ada orang masuk Islam karena ceramahnya. ${ }^{38}$

\section{Dahwah dalam Bentuk Pemberdayaan Masyarakat.}

Dakwah dalam bentuk pemberdayaan masyarakat ini biasanya dilakukan secara kolektif dan terlembaga. Contoh untuk ini adalah Baitul

${ }^{38}$ Ali Azis, Ilmu. h. 3 


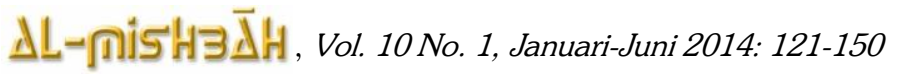

Māl wa Tamwil Insan Sejahtera (BMT Inset) di Kendal Jawa Tengah. Lembaga ini didirikan pada bulan Oktober 1998 dengan prakarsa 20 orang yang masing-masing menyetor modal 400 ribu rupiah, dengan dana total 8 juta rupiah. Mereka telah turut melayani dan mengembangkan sendi-sendi kehidupan pedagang dan pengusaha kecil. Semula BMT Inset hanya menjangkau pedagang-pedagang kecil di sekitar pasar Cepiring dan Pasar Srogol, Kecamatan Brongsong, Kendal. Kemudian, usaha BMT Inset telah merambah di empat kecamatan sekitarnya. Pada awalnya, pinjaman yang diberikan para pedagang sayur, mainan anak dan pedagang pecel sekitar sertus ribu rupiah, BMT Inset tidak memberlakukan bunga tetapi bagi hasil sesuai kerelaan mereka. "Kadang, ada nasabah kami yang memberikan bagi hasil yang jauh lebih tinggi dari pad kalau kami memberlakukan bunga bank". Ujar H. Rafiq H. Khumaidi, ketua pengurus BMT Inset. Dengan sistem ini, setiap tahun ada tambahan keuntungn usaha sekitar 123 juta rupiah lebih. ${ }^{39}$

BMT Inset menyelamatkan masyarakat dari sistem riba dan mengenalkannya dengan sistem bagi hasil dan juga meningkatkan taraf hidup umat Islam yang bisa menjauhkn dari kemaksiatan dan kekufuran. Inilah pesan utama dakwah dari lembaga keuangan syariah lainnya, seperti Bank Muamalat, Takaful Syariah, Reksadana Syariah, BPR Syariah dan sebagainya. Mereka adalah pendakwah dengan pesan dakwah nonverbal, tidak dalam bentuk kata, ucapan, atau tulisan, melainkan dalam kebijakan manajemen.

\section{Dakwah Sang Pelajar}

Ada juga pendakwah yang memfokuskan dakwahnya untuk menyelamatkan iman generasi muslim yaitu yang dilakukan oleh 35 pelajar muslim Indonesia yang tergabung dalam Keluarga Besar Britania Raya (KIBAR). Mereka menulis 2 jilid buku tebal yang berjudul Paket

${ }^{39}$ M. Luthfi Hanafi, Jejak-Jejak Ekonomi Syariah, (Jakarta: Senayan Abadi Publishing, 2003), h.83-85. 
Rahma Dini Warastuti, Fenomena Penggunaan Bahasa....

Permainan Interaktif Pendidikan aqidah untuk Anak TK. Buku ini menjadi pegangan guru Islam yang mengajar keimanan untuk anakanak diplomat, pelajar ataupun pekerja di Inggris. Menurut Geovanni, pemrakarsa penulisan, terbitannya buku tersebut dilatarbelakangi oleh kesulitan dalam pengajaran agama bagi anak-anak muslim di Sheffield dan Inggris pada umumnya, hal ini dikarenakan anak-anak di Inggris dibiasakan untuk bersikap kritis termasuk di dalam masalah agama, sehingga model pendidikan agama di Indonesia tidak bisa diterapkan sama sekali di Inggris. ${ }^{40}$

Usaha KIBAR tersebut dapat dikatakan sebagai kegiatan dakwah dengan tulisan. Siapapun bisa menjadi pendakwah dengan menulis pesan Islam di majalah, koran, atau internet. Pendakwah melalui tulisan melebihi jangkauan dakwah ceramah yang hanya ditangkap terbatas pada mereka yang hadir atau mendengarkan pendakwah tulisan tidak dituntut lancar bacaan Alqurān dan pesan dakwahnya ditangkap oleh massa yang membacanya. Jika tulisan tersebut didokumentasi, didiskusikan, dijadikan wacana, maka pada akhirnya sang penulis dapat menjadi tokoh yang mengubah masyarakat secara kultural.

\section{Dakwah Seorang Pekerja Perfilman}

Akhir abad XX ini adalah masa terjadinya banjir media massa dan menjurus kepada terjadinya kekerasan media massa yang sukar diabaikan oleh pembentuk-pembentuk watak manusia. Media massa seperti surat kabar, televisi, radio, film, teater, majalah dan sebagainya, oleh para da'i harus dimanfaatkan seefektif mungkin, sebab bila tidak demikian, media tersebut akan cenderung berupa alat sekularisasi yang akan mendangkalkan penghayatan keagamaan umat Islam.

Mengingat pentingnya pemanfaatan media massa tersebut, maka diperlukan teknik penyajian yang menarik, seperti penggunaan kesenian dan kebudayaan untuk dakwah, cerita-cerita rakyat seperti wayang dan lakon-lakon lainnya, ceramah agama. Karena itu pemanfaatan media

${ }^{40}$ Ali Azis, Ilmu. h. 4 


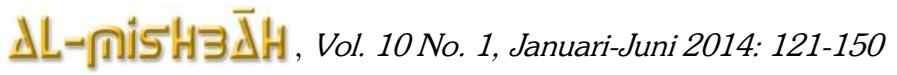

secara efektif memerlukan keterampilan dan keahlian bagi pemakai media itu. Oleh karena itu, saat ini telah bermunculan para aktivis dakwah yang hadir di dunia perfilman. Dakwah melalui film lebih komunikatif sebab materi dakwah dapat diproyeksikan dalam suatu skenario film yang memikat dan menyentuh keberadaan masyarakat dalam kehidupan sehari-hari. Pemanfaatan film cenderung lebih efektif dan efisien serta sangat aktual sesuai dengan perkembangan masyarakat. Hal ini disadari karena film membawa pesan yang mampu mempengaruhi penontonnya sebagai sasaran dakwah mad'u-nya. Itulah sebabnya film dalam kegiatan dakwah seharusnya ditata rapi dan mengandung nilai-nilai ajaran moral islami yang sesuai dengan kebutuhan mad'ū-nya. ${ }^{41}$

Kesuksesan film Ayat-Ayat Cinta (AAC) menyedot perhatian seluruh lapisan masyarakat (termasuk presiden dan para petinggi negeri ini lainnya). Hal in menjadikan sebagian aktivis dakwah tertarik untuk turut berdakwah melalui film. Menyusul AAC, kini telah dirilis "film dakwah" Kun Fa Yakun (KFY) dan kabarnya karya best seller Kang Abik lainnya, Ketika Cinta Bertasbih (KCB) pun turut difilmkan. Menurut mereka, berdakwah melaui nasihat yang disampaikan tanpa terkesan menggurui adalah melalui film,. Dari sekian banyak media massa yang ada, maka film merupakan salah satu media massa yang sangat efektif dalam pelaksanaan dakwah. Film memiliki daya tarik tersendiri, dan dapat disajikan dalam berbagai bentuk dan variasi sehingga dapat menimbulkan daya tarik bagi penontonnya.

Mc. Quail dalam bukunya mengatakan bahwa pemanfaatan film dalam usaha pembelajaran masyarakat sebagian didasari oleh pertimbangan bahwa film mempunyai kemampuan untuk menarik perhatian orang dan sebagian lagi didasari oleh alasan bahwa film mempunyai kemampuan mengantar pesan secara unik. ${ }^{42}$

${ }^{41}$ M. Bahri Ghazali, Dakwah Komunikatif: Membangun Kerangka Dasar Ilmu Komunikasi Dakwah, (Cet. I; Jakarta: Pedoman Ilmu Jaya, 1997), h. 39-40

${ }^{42}$ McQuail, Denis McQuail, Mass Communication Theory: An Introduction, 3th edition, (London: SAGE Publication, 1994), h.13 
Rahma Dini Warastuti, Fenomena Penggunaan Bahasa....

Namun demikian, agar para artis film dapat berperan sebagai pendakwah, maka ada banyak larangan-larangan syariah yang harus diperhatikan. Pertama, tidak mengumbar aurat dengan lawan pemain yang bukan muhrim. Kedua, tidak terjadi ikhtilat baik pada saat latihan maupun pada saat take adegan dan ketiga, objek dakwah (mad'ü) dipastikan tidak menonton film yang diberisi adegan haram. ${ }^{43}$

Semoga film-film maupun sinetron yang dibintangi oleh para pemain muslim dapat menjadi media jihad yang efektif untuk menyentuh sanubari dan keimanan diri pemain sendiri sebagai pendakwah dan para penonton sebagai mad'u-nya.

\section{Penutup}

Demi tercapainya tujuan dakwah, maka sangat perlu memperhatikan pemilihan metode dakwah. Baik melalui bahasa verbal yaitu melalui lisan maupun nonverbal. Berdakwah melalui lisan, biasanya dalam bentuk ceramah, khutbah, diskusi maupun obrolan. Metode lisan yang paling dikenal oleh masyarakat adalah dakwah dalam bentuk ceramah dan khutbah yang dihadiri oleh khalayak ramai, oleh sebab itu pendakwahnya dikenal demngan sebutan da'i. Bentuk penyampaian dakwah yang kedua adalah dakwah yang menggunakan bahasa nonverbal biasanya berupa pemberian contoh yang baik, hikmah, pemberdayaan dan lain sebagainya. Metode yang kedua ini dapat dilakukan oleh siapa saja dengan latar belakang profesi yang beragam. Sebagai seorang muslim sekaligus pedakwah, pasti menempuh berbagai macam cara demi terlaksanakannya suatu dakwah .dakwah adalah sesuatu yang urgensi, karena keadaan dunia saat ini sudah jauh lebih berkembang dan alur masuknya berbagai macam informasi negatif yang begitu cepat. Oleh karena itu, para kader dakwah harus menguasai semua bidang yang ada. Dari politik, kesehatan, perdagangan, perekonomian, media massa, bahkan sampai bidang

${ }^{43}$ Efendi P., "Dakwah Melalui Film”, http://altajdidstain.blogspot.com/2011/02 /dakwah-melalui-film_09.html, diakses 3 Mei 2014 


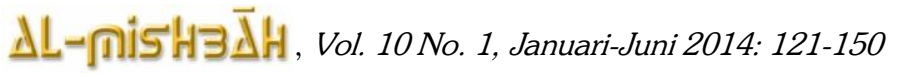

kesenian. Namun, bidang-bidang ilmu tersebut tentu akan sulit dikuasai hanya oleh segelintir orang saja, demi kesuksesan dakwah ini, perlu dibentuk gerakan dakwah yang berorientasi pada minat dan bakat dari setiap orang terhadap profesinya. Untuk mewujudkannya, setiap diri muslim dengan berbagai latar belakang profesi, bersama-sama berdakwah walaupuan dengan beragam pendekatan, metode dan situasinya. Setiap diri muslim yang menyadari dirinya sebagai pendakwah dan harus mencoba sekuat tenaga, walaupun pada akhirnya hasil diserahkan kepada Allah. Memberikan hidayah bukan kuasa manusia, melainkan kuasa Allah semata. Kita hanya berkewajiban menyampaikan; Allahlah yang akan memberikan petunjuk serta memberikan balasan, baik kepada yang mendapat hidayah maupun yang tersesat.

Intinya, untuk mengantisipasi tren masyarakat modern harus dapat mempersiapkan materi-materi dakwah yang lebih mengarah pada antisipasi kecenderungan-kecenderungan masyarakat. Oleh karena itu, maka seluruh komponen dan segenap aspek yang menentukan atas keberhasilan dakwah harus ditata secara professional dan disesuaikan dengan kondisi mad'ù agar dapat menghasilkan kemasan dakwah yang benar-benar mampu memperbaiki dan maningkatkan semangat dan kesadaran yang tulus dalam mengaktualisasikan nilai-nilai ajaran Islam Setiap pendakwah harus berniat karena ibadah, semoga amal para pendakwah ini dihitung sebagai amal dakwah dan bernilai ibadah di mata Allah. Amin. 
Rahma Dini Warastuti, Fenomena Penggunaan Bahasa....

\section{Daftar Pustaka}

Ali Aziz, Moh, Ilmu Dakwah, Jakarta: Kenvana, 2009.

Bahtar, Ilmu Dakwah: Paradigma untuk Aksi, Palu: Sulteng Center Press, 2013

Bersama Dakwah, "Alhamdulillah, Pengadilan Turki Cabut Larangan Jilbab bagi Pengacara" http://www.bersamadakwah.com /2013/11alhamdulillah-pengadilan-turki-cabut.html, diakses 2 Mei 2014

Dakwatuna.com, "Peran Pemuda dalam Gerakan Dakwah", http://www.dakwatuna.com/2007/10/18/286/ peranpemuda-dalam-gerakan-dakwah/\#axzz34g1gFmhJ, diakses 2 Mei 2014

Edy, Ayah, I Love U Ayah Bunda, Jakarta: PT Mizan Publika, 2009.

Efendi, $\mathrm{P}$., "Dakwah Melalui Film", http://altajdidstain.blogspot.com/2011/02/dakwah-melaluifilm 09.html. diakses 3 Mei 2014

Effendy, Onong Uchjana, Ilmu, Teori dan Filsafat Komunikasi, Cet. II. Bandung: PT. Citra Aditya Bakti, 2000.

Ghazali, M. Bahri, Dakwah Komunikatif: Membangun Kerangka Dasar Ilmu Komunikasi Dakwah, Cet. I. Jakarta: Pedoman Ilmu Jaya, 1997.

Hamidi, M. Luthfi, Jejak-jejak Ekonomi Syariah, Jakarta: Senayan Abadi Publishing, 2003.

Harahap, Syahrin, Islam dan Implementasi Pemberdayaan, Cet. I. Yogyakarta: PT. Tiara Wacana Yogyakarta, 1999.

Hasbullah, Moeflich, "Kisah Dosen UIN Mem-booking 8 PSK dalam Satu Kamar" http://moeflich.wordpress.com/2012/07/02/kisahdosen-uin-mem-booking-8-psk-dalam-satu-kamar/, diakses 2 Mei 2014

Idris, Malik. Strategi Dakwah Kontemporer. Cet. I. Makassar: Sawah Press. 2007.

M. Canard, "Da'wa", The Encyclopedia of Islam, B.lewis (et.a) Vol.II. Leiden: E.J.Brill. 1991.

McQuail, Denis, Mass Communication Theory: An Introduction. 3th edition, London: SAGE Publication, 1994. 


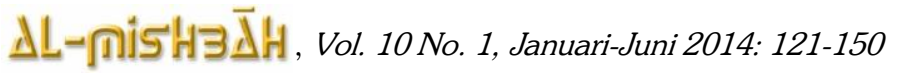

Muharrik, Dakwah "Dr. Sayyid Ismail, Sang Dosen Hafidz Quran ini Syahid. http://www.muharrikdakwah.com/2014/04/ dr-sayyidismail-sang-dosen-hafidz.html, diakses 3 Mei 2014

Muhidin, Asep, Dakwah dalam Perspektif Al Qur'an, Bandung: Pustaka Setia, 2002.

Munir, M, Metode Dakwah, Edisi Revisi, Cet III. Jakarta: Kencana, 2006.

Muriah, Siti, Metode Dakwah Kontemporer, Yogyakarta: Mitra Pustaka, 2000.

Shihab, M.Qurais, Membumikan Alqurān, Fungsi dan Peran Wahyu dalam Kehidupan Masyarakat. Cet.VII; Bandung: Mizan, 1994.

Wardi Bahtiar, Metodologi Penelitian Ilmu Dakwah, Cet. I; Jakarta: Logos Wacana Ilmu, 1997.

Warson Munawwir, Ahmad, Al-Munawwir Kamus Arab-Indonesia, Surabaya: Pustaka Progresif, 1997.

Ya'kub, Ali Musthafa, Sejarah Dan Metode Dakwah Nabi. Jakarta: Pustaka Firdaus, 1997. 